\title{
Risk stratification in patients with coronary heart disease before cardiac surgery
}

\author{
O. K. Gogayeva A. V. Rudenko, V. V. Lazoryshynets
}

Amosov National Institute of Cardiovascular Surgery, Kyiv

\section{Стратифікація ризику у пацієнтів з ішемічною хворобою серця перед кардіохірургічною операцією}

\author{
О. К. Гогаєва, А. В. Руденко, В. В. Лазоришинець
}

Національний інститут серцево-судинної хірургії імені М. М. Амосова НАМН України, м. Київ

\begin{abstract}
Objective. To analyse the risk stratification effectiveness for calculators EuroSCORE I, EuroSCORE II, STS in patients with ischemic disease before cardiac surgery.

Materials and methods. Retrospective analysis of data was conducted from randomized 194 patients with coronary artery disease who were discharged from the Amosov National Institute of Cardiovascular Surgery after coronary artery bypass surgery in the period $2009-2019$. An average age of patients was (64.2 \pm 8.9). In all patients clinical and laboratory studies, echocardiography, electrocardiography, coronary angiography as well as surgical revascularization were conducted. Preoperative risk stratification was performed using three available calculators Euro SCORE I, EuroSCORE II and STS.

Results. There was no mortality in the study group of patients, while the predicted surgical mortality on the EuroSCORE I scale was $25.02 \%$, EuroSCORE II $-7.78 \%$, STS $-2.84 \%$. According to the results of twenty years period of the Amosov National Institute of Cardiovascular Surgery in the surgical treatment of coronary heart disease in more than 15,000 patients, mortality from coronary heart disease was less than $0.6 \%$, which is much less than the predicted mortality rates.

Conclusions. Prior to surgery, risk stratification of patients should be performed on appropriate scales to understand their baseline status. The EuroSCORE II scale is optimal for use in modern cardiac surgery. Surgery in patients with a high estimated risk (EurOSCORE II > 5\%) should be performed by an experienced cardiac surgeon with more than 10 years of cardiac surgery experience.

Keywords: risk scales; EuroSCORE II; coronary heart disease; patient category of high risk; comorbidity.

Реферат

Мета. Проаналізувати ефективність стратифікації ризику за калькуляторами EuroSCORE I, EuroSCORE II, STS у пацієнтів з ішемічною хворобою серця перед кардіохірургічною операцією.

Матеріали і методи. Проведений ретроспективний аналіз даних випадкових 194 пацієнтів 3 ішемічною хворобою серця, які були виписані з Національного інституту серцево-судинної хірургії імені М. М. Амосова після операції коронарного шунтування в період 2009 - 2019 рр. Середній вік пацієнтів становив $(64,2 \pm 8,9)$ року. Усім пацієнтам були проведені клініко-лабораторні дослідження, ехокардіографія, електрокардіографія, коронарографія та виконана хірургічна реваскуляризація міокарда. Передопераційна стратифікація ризику проводилась за трьома доступними калькуляторами: EuroSCORE I, EuroSCORE II та STS.

Результати. Летальності у досліджуваній групі пацієнтів не було, у той час як прогнозована операційна летальність за шкалою EuroSCORE I становила 25,02\%, EuroSCORE II - 7,78\%, STS - 2,84\%. Згідно з результатами двадцятирічного досвіду Національного інституту серцево-судинної хірургії імені М. М. Амосова в хірургічному лікуванні ішемічної хвороби серця білыше ніж у 15000 паціентів, летальність при ішемічній хворобі серця становила менше 0,6\%, що значно менше прогнозованої летальності за всіма зазначеними шкалами.

Висновки. Напередодні оперативного втручання необхідно проводити стратифікацію ризику у пацієнтів за відповідними шкалами для розуміння їх вихідного статусу. Оптимальною для використання в сучасній кардіохірургічній практиці $€$ шкала EuroSCORE II. Оперативне втручання пацієнтам з високим розрахунковим ризиком (EuroSCORE II $>5 \%$ ) має виконувати досвідчений кардіохірург, кардіохірургічний стаж якого перевищує 10 років.

Ключові слова: шкали ризику; EuroSCORE II; ішемічна хворода серця; пацієнт категорії високого ризику; коморбідність.
\end{abstract}

Scientific progress has led to rapid development in the medical sector, and improvements in surgical myocardial revascularisation techniques have made it possible to successfully operate on patients of different ages, with varying degrees of severity and comorbidities $[1,2]$. The possible risk of complications and mortality is calculated after analysis of cardiac status and comorbid conditions before surgery. Three risk stratification scores are available to cardiac surgeons: two European scales, EuroSCORE I
(ES I) and EuroSCORE II (ES II), and the American Society of Cardiothoracic Surgeons STS score [3-5]. A patient is classified as a high-risk one щfor mortality if there is a score above 6 on the additive ES I calculator [4], above 5\% on the logistic ES I calculator $[6,7]$ and above $5 \%$ on the ES II calculator [8].

When the economic component was studied according to patient severity, it appeared that a high EuroSCORE rate was associated with higher post-operative mortality, more 
complications and length of hospital stay, as well as the costs [9].

The study objective was to compare the effectiveness of the ES I, ES II and STS prognostic scores in cardiac surgical patients with ischaemic heart disease (IHD).

\section{Materials and methods}

A retrospective data analysis of 194 random IHD patients who were discharged after coronary artery bypass surgery (CABS) from the Department of Surgical Treatment of IHD of the Amosov National Institute of Cardiovascular Surgery NAMS of Ukraine between 2009 and 2019 was conducted. The average age of the patients was (64.2 \pm 8.9$)$ yrs old. All the patients underwent clinical and laboratory examination, electrocardiography (ECG), echocardiography (EchoCG), coronary ventriculography (CVG) and surgical myocardial revascularisation. ECG was recorded on SCHILLER CARDIOVIT 100, MAC 1200 ST, MIDAS-EC1T at a paper speed of $50 \mathrm{~mm} / \mathrm{s}$ in 12 standard leads. The dynamics of ECG values were analysed on the day of surgery and every 24 hours after surgery, compared to the ECG values on admission. Echocardiography was performed on TOSHIBA-6000, SIEMENS ACUSON CV 70 devices in $\mathrm{M}-$ and $\mathrm{B}-$ modes with a $3.5 \mathrm{MHz}$ sensor according to the standard method. A complete EchoCG study was performed on admission, free fluid in the pericardial and pleural cavities was assessed after surgery, and the ejection fraction (EF) was measured. The CVG was performed, using COROSCOP TOR, AXIOM, TOSHIBA, using the standard techniques either through the femoral artery using the Judkins method or through the radial artery, using the Sones method. Three available calculators were used for the preoperative risk stratification: ES I, ES II and STS. Kidney function was assessed by the glomerular filtration rate, calculated, using the Chronic Kidney Disease Epidemiology Collaboration (CKD-EPI) formula. Creatinine clearance, which is required for the ES II risk stratification, was calculated using the Cockcroft-Gault formula. Coronary artery bypass grafting was performed, using standard techniques on a working heart or in the condition of artificial blood circulation (ABC). All the patients provided the informed written agreement to participate in the scientific study, the protocol of which was approved at a meeting of the Biomedical Ethics Commission of the Amosov National Institute of Cardiovascular Surgery. According to the conclusion of the commission, the study does not restrict the rights of patients, and its moral and ethical standards were in line with the basic provisions of good medical practice GSP CCI and current laws of Ukraine. Patients with IHD, who required surgical myocardial revascularisation and signed the informed consent to participate in the study, and who were classified as being in a high risk (more than 5\% mortality probability), when risk was stratified by the ES II scale, were included in the study. The patients' database was created in Microsoft Excel 2010 with the possibility of calculating the average value and the uncertainty of the mean, and statistical processing was performed, using the Statistica for Windows software package (StatSoft Inc.). Differences were considered statistically significant if the $\mathrm{p}-$ value was less than 0.05 .

\section{Results}

All the patients had stenotic coronary atherosclerosis, requiring surgical revascularization. Hypertension was observed in 192 (99.0\%) patients. At the time of hospitalization, 165 (85.1\%) patients had complaints of anginal pain, angina pectoris and stress IV functional class (FC), diagnosed in $52(26.8 \%)$ patients, III FC - in 107 (55.2\%), II FC - in 5 (2.6\%), I FC - in 1 (0.5\%) patient, and a painless form - in 29 (14.9\%). Unstable angina pectoris was found in 84 (43.3\%) and an acute myocardial infarction - in 12 (6.2\%) patients. The heart failure IV FC, according to the New York Heart Association of Chronic Heart Failure (NYHA), was detected in 7 (3.6\%) patients, III FC - in 135 (69.6\%), and II FC - in 52 (26.8\%) patients.

$\mathrm{EF}$ of the left ventricle (LV) have averaged (48.6 \pm 8.7$) \%$. The LV EF over 50\% was revealed in 105 (54,1\%) patients, LV EF $31-50 \%$ - in 84 (43,2\%), and significant decrease of the LV myocardial contractility (LV EF $21-30 \%$ ) - in 5 ( $2,6 \%)$. Pulmonary hypertension was detected in $69(35,6 \%)$ patients.

Analysis of comorbidities have showen, that patients had a high co-morbidity index. Thus, type 2 diabetes mellitus (DM) was found in $50(25.8 \%)$ patients, chronic obstructive pulmonary disease (COPD) - in 149 (76.8\%), with an average vital capacity of (94.4 $\pm 12.9 \%)$. Stenosis of the internal carotid arteries more than 50\% during duplex scanning of brachiocephalic arteries was detected in 60 (30.9\%) patients. Obliterative atherosclerosis of the arteries of the lower extremities was verified in 125 (64.4\%) patients. Varicose veins of the lower extremities with trophic changes and lymphostasis, which corresponded to the C4 - C6 class, according to the clinical-etiological-anatomicalpathophysiological classification (CEAP), were found in 44 (22.7\%) patients, and the initial changes (C1-C3 class) - in 58 (30.0\%). Venectomy was found in the history of 9 (4.6\%) patients. 86 (44.3\%) were overweight, 74 (38.1\%) - obese, and $138(71.1 \%)$ indicated smoking. Acute cerebrovascular event (ACE) in the anamnesis was found in 27 (13.9\%) patients, 75 (38.7\%) had a chronic kidney disease (CKD), $20(10.3 \%)$ had gout, and 20 (10.3\%) had a gastric ulcer.

If you have detailed information about the patient, you can calculate the risks before surgery using the scores. Information on gender, the age, $\mathrm{EF}, \mathrm{CKD}$, severe COPD, peripheral and brachiocephalic artery disease, instability, pulmonary hypertension, and volume of cardiac surgery is required to stratify the risk on the ES I scale. With the help of this calculator you can calculate two indicators - additive ES (ES ad.), which indicates the number of the risk factors, and logistical ES (ES log.). The ES I risk stratification of the patients yielded an ES I ad. 9.3 (range 5 - 20), ES I log. $25.02 \%$ (range $6.86-89.62 \%$ ). Patients had an average of around 9 risk factors, according to the ES I ad. indicator, 
which could affect the surgery prognosis. One in 4 patients could have been refused surgery because of the very high risk of mortality, based on the ES I log. These patients were denied surgery precisely in the formative stages of IHD surgery, with no chance of recovery or improvement in quality of life (QoL). The results of the ES I risk calculations suggest, that the ES I scale significantly increases the risks and is not appropriate for use in the current cardiac surgery.

The European ES II risk scale, updated in 2011, has been supplemented with preoperative indicators, such as creatinine clearance, which is determined by the CockcroftGault formula, insulin dependence for type 2 diabetes, presence of angina pectoris type IV, degree of pulmonary hypertension, unanticipated surgical intervention and number of surgical manipulations during surgery. The risk of mortality on the ES II scale have averaged 7.78\% (range $5.01-68.25 \%)$.

Calculation on the STS scale is longer, the calculation of risks for one patient takes an average of $25-30 \mathrm{~min}$. The STS risk stratification takes into account more than 60 indicators, including data from the patient's health insurance, the race, anthropometry, detailed medication therapy, special attention to antiplatelet therapy and the timing of its withdrawal; hypoglycaemic therapy in type 2 diabetes and its degree of compensation; information on bad habits, not limited to smoking, also are taken into account the antidepressant therapy and drug use, the alcohol abuse; family history of a sudden death; the sleep apnoea syndrome; the cancer history; chest radiation therapy; bronchopulmonary involvement, duration of pneumonia and oxygen dependency; the detailed cardiac rhythm disturbances by duration and type of arrhythmia and block; cardiac surgical history, not limited to sternotomy, endovascular and arrhythmic procedures are also taken into account. The degree of stenosis, regurgitation on heart valves are analyzed at echocardiography. The CVG data are also taken into account, namely the number of the stenosed coronary arteries, the degree of stenosis of the main trunk and proximal anterior interventricular branch of the left coronary artery. The risk of mortality was $2.84 \%$ (range $0.43-42.2 \%$ ), according to the STS scale. We provide brief information about the operative and postoperative periods in patients, given that the STS database includes 8 additional indicators of postoperative complications.

The emergency surgery was performed in 55 (28.4\%) patients. Coronary artery bypass was performed on the working heart in 187 patients, while in the ABC conditions in 7 (3.7\%) patients. The average number of shunts was 3.37 \pm 0.9 , the internal thoracic artery was used in 167 (86.1\%) patients. The average duration of artificial lung ventilation (ALV) was $(7.4 \pm 4.07)$ hours. In the postoperative period, ACE have occurred in 4 (2.1\%) patients, transient ischaemic attack (TIA) - in 2 (1.0\%), retoracotomy - in 2 (1.0\%), who received antiaggregants on the day of surgery. The sternal wound infection have occurred in 5 patients, including 2 (1.0\%) with type 2 DM; prolonged ALV (over $24 \mathrm{~h}$ ) was performed in $3(1.5 \%)$ patients. A 50\% increase in the serum creatinine indicates ane acute renal failure (ARF), which have occurred in $2(1.0 \%)$ patients after CABS, but did not require haemodialysis and was transient.

All the patients were discharged from the institute at an average of ( $8.4 \pm 3.5)$ days. A long stay (more than 14 days) in the institute after CABS was in 12 (6.2\%) patients, a short stay (less than 6 days) - in 53 (27.3\%). The table shows the results of calculations for the risk of complications on all scales (for the STS scale, additional indicators are shown).

\section{Discussion}

No surgical treatment is without a risk. In the world of the evidence-based medicine the risk stratification for the patients is mandatory in order to understand the further treatment tactics and possible economic costs. The FIASCO (the failure to achieve a satisfactory cardiac outcome) study [10] have examined the post-operative mortality in the low-risk patients with ES $\leq 2$. Sixteen (0.37\%) of the 4,294 low-risk patients, who underwent surgery, died. The authors have concluded, that 9 deaths could not have been prevented (ACE, bronchopneumonia, etc.) and 7 were avoidable, because they were caused by technical errors, including 3 deaths, caused by the additional system errors. Thus, almost half of the deaths could have been avoided, despite the extremely low predicted mortality in the lowrisk patients.

The risk of post-operative complications and the probability of mortality are increasing while the severity of the patient's condition enhances. We have randomised 194 a high-risk patients (ES II> 5\%) into our study to assess the effectiveness of the stratification scales. There was no hospital mortality, despite the initial severity of the patients and a high predicted ES II mortality of (7.78 \pm 2.4$) \%$.

The literature continues to discuss the question of which scale of the risk to prefer in practice. Serbian authors [11] have compared the results of the risk stratification in 1864 patients on the scales ES I and ES II. The operative mortality was $3.65 \%$, the predicted mortality, according to the scales ES I ad., ES I log. and ES II - 5.14, 6.60 and 3.51\%, respectively. The ES II calculator was characterized by very good discrimination and calibration ability, as well as the optimal prognosis of long-term stay of the patients after cardiac surgery in the intensive care unit. However, after analysing the data from 933 patients, N. J. Howell et al [12] have concluded, that the risk prediction in the high-risk ES II patients was no better than for ES I ad. and ES I log. The problem of the risk stratification in the high-risk patients requires further research and application of better statistical methods in the specific algorithms development. Moreover, the models, predicting the postoperative complications and mortality may be more valuable [12]. The relative calibration and discrimination rates of the ES II and STS calculators were found to be similar in large groups of patients who underwent different cardiac surgical procedures, according to P. G. Sullivan et al [13]. The predicted mortality rates for 


\begin{tabular}{|c|c|c|c|c|c|}
\hline \multirow{3}{*}{ Indicator } & \multicolumn{3}{|c|}{ Indicator value } & \multirow{2}{*}{\multicolumn{2}{|c|}{ Number of patients }} \\
\hline & \multirow{2}{*}{$\begin{array}{l}\text { Average } \\
\text { value }\end{array}$} & \multirow{2}{*}{$\begin{array}{c}\text { Minimal } \\
\text { value }\end{array}$} & \multirow{2}{*}{$\begin{array}{l}\text { Maximum } \\
\text { value }\end{array}$} & & \\
\hline & & & & $\mathrm{n}$ & $\%$ \\
\hline ES I ad., n & $9,3 \pm 2,9$ & 5 & 20 & - & - \\
\hline ES I log., \% & $25,02 \pm 14,38$ & 6,86 & 89,62 & - & - \\
\hline ES II, \% & $7,78 \pm 2,4$ & 5,01 & 68,25 & - & - \\
\hline \multicolumn{6}{|l|}{ STS, $\%$} \\
\hline mortality & $2,8 \pm 2,2$ & 0,43 & 42,2 & - & - \\
\hline ARF & $2,48 \pm 2,3$ & 0,05 & 60,6 & 2 & 1,0 \\
\hline ACE,TIA & $1,5 \pm 0,9$ & 0,4 & 6,8 & 6 & 3,1 \\
\hline prolonged ALV & $10,9 \pm 8,7$ & 3,05 & 82,8 & 3 & 1,5 \\
\hline reoperation, including retroracotomy & $2,85 \pm 1,2$ & 1,07 & 8,1 & 2 & 1,0 \\
\hline sternal wound infection & $0,3 \pm 0,17$ & 0,09 & 1,3 & 5 & 2,6 \\
\hline morbidity and mortality rates & $16,5 \pm 10,6$ & 5,6 & 91,4 & 18 & 9,3 \\
\hline long stay in the hospital & $6,6 \pm 6,3$ & 1,15 & 64,8 & 12 & 6,2 \\
\hline short stay in the hospital & $40,9 \pm 15,3$ & 1,5 & 74,4 & 53 & 27,3 \\
\hline
\end{tabular}

ES II were almost three times higher than the similar indicators for STS, according to our study.

The Turkish authors [14] also have compared all three the risk prediction scales from analysis of data from 428 patients and concluded, that the ES II significantly underestimates the risk of mortality, whereas the additive and logistic ESI risk calculators and STS calculator are well calibrated.

The tactics of treatment in the patients can not be entirely based on the risk assessment, according to the recommendations of the European Society of Cardiology (ESC) and the European Association of Cardiothoracic Surgery (EACTS) for myocardial revascularization in 2018. This data can only be used as information material when discussing the patient with a cardio team [3].

F. A. Atik et al [15] have studied the effect of the surgery type and the experience of the cardiac surgeon on the ESI risk score in a group of 2320 patients. The mortality, predicted by the ES I, have correlated with the mortality observed $(\mathrm{O} / \mathrm{E}=0.94 ; \mathrm{p}<0.0001$; and the area under the ROC curve 0.78). However, on the ES I scale, the mortality of patients at very high risk was overestimated $(\mathrm{O} / \mathrm{E}=$ $0.74 ; \mathrm{p}=0.001)$. The ES I scale have also overestimated the mortality in patients, who should have been operated on by surgeon $\mathrm{A}(\mathrm{O} / \mathrm{E}=0.46 ; \mathrm{p}<0.0001)$ and underestimated the mortality in patients, who should have been operated on by surgeon $\mathrm{B}(\mathrm{O} / \mathrm{E}=1.3, \mathrm{p}<0.0001)$ in each risk category. Thus, the ES calculator overestimates the mortality of patients at very high risk, depending on the type of procedure and the surgical team. The most appropriate surgical team can minimise the risks of pre-operative profiles [15].

We analysed the practical experience of cardiac surgeons, who have performed CABS in a high-risk patients and found, that cardiac surgeons have an average of ( $24 \pm 12.5)$ yrs of the experience gained (ranging from 10 to 45 years).

The mortality rate was less than $0.6 \%$, which is much lower than predicted by all the scales studied, based on the twenty years experience of the Department of Surgical Treatment of IHD at the Amosov National Institute of Cardiovascular Surgery NAMS of Ukraine in the surgical treatment of more than 15, 000 patients, suffering IHD. These results were realized due to the work of a highly qualified cardiac team, conduction of the pre-operative risk stratification in the patients, as well as a timely identification of comorbid conditions and their compensation, achieved in the preoperative phase.

\section{Conclusions}

1. The risk stratification in patients, using the known scales, should be performed before surgery to understand their baseline status. The ES II scale is optimal for use in modern cardiac surgery.

2. The STS scale can be used to predict the additional post-operative complications (the risk for ARF, ACE, resurgery, prolonged ALV, etc.). Application of the ES I scale is inappropriate due to significant overestimation of the surgical mortality risk, but it is possible to use ES I and. to understand the risk factors quantity.

3. An experienced cardiac surgeon with more than 10 years' experience of cardiac surgery should perform the surgery in patients with a high calculated risk (ES II $>5 \%$ ).

Financing. The funds of the authors have been used. The authors did not receive any remuneration from the producing firms, including competitors that could influence the results of the study. This study did not apply for any grants.

Contribution of each participant. Gogayeva O.K. - research concept, analysis and statistical processing of material, graphic design; Rudenko A.V. - research design, topic editing; Lazoryshynets V.V. - research design.

Conflict of interest. The authors have no conflict of interest.

Consent to publication. The authors approved the final version of the article and agreed to publish this manuscript. 


\section{References}

1. Ghanta RK, Shekar PS, McGurk S, Rosborough DM, Aranki SF. Long-term survival and quality of life justify cardiac surgery in the very elderly patient. Ann Thorac Surg. 2011 Sep;92(3):851-7. doi: 10.1016/j.athoracsur.2011.04.083. PMID: 21871269.

2. Järvinen O, Hokkanen M, Huhtala H. Quality of life 12 years after on-pump and off-pump coronary artery bypass grafting. Coron Artery Dis. 2013 Dec;24(8):663-8. doi: 10.1097/ MCA.0000000000000037. PMID: 24100406.

3. Neumann FJ, Sousa-Uva M, Ahlsson A, Alfonso F, Banning AP, Benedetto U, et al. 2018 ESC/EACTS Guidelines on myocardial revascularization. Eur Heart J. 2019 Jan 7;40(2):87-165. doi: 10.1093/ eurheartj/ehy394. Erratum in: Eur Heart J. 2019 Oct 1;40(37):3096. PMID: 30165437.

4. Nashef SA, Roques F, Michel P, Gauducheau E, Lemeshow S, Salamon R. European system for cardiac operative risk evaluation (EuroSCORE). Eur J Cardiothorac Surg. 1999 Jul;16(1):9-13. doi: 10.1016/s1010-7940(99)00134-7. PMID: 10456395.

5. Shahian DM, O'Brien SM, Filardo G, Ferraris VA, Haan CK, Rich JB, et al. The Society of Thoracic Surgeons 2008 cardiac surgery risk models: part 1 - coronary artery bypass grafting surgery. Ann Thorac Surg. 2009 Jul;88(1 Suppl):S2-22. doi: 10.1016/j.athoracsur.2009.05.053. PMID: 19559822.

6. Ranucci M, Castelvecchio S, Menicanti LA, Scolletta S, Biagioli B, Giomarelli P. An adjusted EuroSCORE model for high-risk cardiac patients. Eur J Cardiothorac Surg. 2009 Nov;36(5):791-7. doi: 10.1016/j.ejcts.2009.02.023. Epub 2009 Apr 8. PMID: 19359191.

7. Kunt AS, Darcin OT, Andac MH. Coronary artery bypass surgery in high-risk patients. Curr Control Trials Cardiovasc Med. 2005 Aug 26;6(1):13. doi: 10.1186/1468-6708-6-13. PMID: 16124878; PMCID: PMC1224861.

8. Kar P, Geeta K, Gopinath R, Durga P. Mortality prediction in Indian cardiac surgery patients: Validation of European System for Cardiac Operative Risk Evaluation II. Indian J Anaesth. 2017 Feb;61(2):157-62. doi: 10.4103/ija.IJA_522_16. PMID: 28250485; PMCID: PMC5330073.

9. Titinger DP, Lisboa LA, Matrangolo BL, Dallan LR, Dallan LA, Trindade EM, et al. Cardiac surgery costs according to the preoperative risk in the Brazilian public health system. Arq Bras Cardiol. 2015 Aug;105(2):130-8. doi: 10.5935/abc.20150068. Epub 2015 Jun 23. PMID: 26107813; PMCID: PMC4559121.
10. Freed DH, Drain AJ, Kitcat J, Jones MT, Nashef SA. Death in low-risk cardiac surgery: the failure to achieve a satisfactory cardiac outcome (FIASCO) study. Interact Cardiovasc Thorac Surg. 2009 Oct;9(4):623-5. doi: 10.1510/icvts.2009.208371. Epub 2009 Jul 14. PMID: 19602493.

11. Nezic D, Spasic T, Micovic S, Kosevic D, Petrovic I, Lausevic-Vuk L, et al. Consecutive Observational Study to Validate EuroSCORE II Performances on a Single-Center, Contemporary Cardiac Surgical Cohort. J Cardiothorac Vasc Anesth. 2016 Apr;30(2):345-51. doi: 10.1053/j.jvca.2015.11.011. Epub 2015 Nov 7. PMID: 26873386.

12. Howell NJ, Head SJ, Freemantle N, van der Meulen TA, Senanayake E, Menon A, et al. The new EuroSCORE II does not improve prediction of mortality in high-risk patients undergoing cardiac surgery: a collaborative analysis of two European centres. Eur J Cardiothorac Surg. 2013 Dec;44(6):1006-11; discussion 1011. doi: 10.1093/ejcts/ezt174. Epub 2013 Mar 27. PMID: 23536616.

13. Sullivan PG, Wallach JD, Ioannidis JP. Meta-Analysis Comparing Established Risk Prediction Models (EuroSCORE II, STS Score, and ACEF Score) for Perioperative Mortality During Cardiac Surgery. Am J Cardiol. 2016 Nov 15;118(10):1574-82. doi: 10.1016/j. amjcard.2016.08.024. Epub 2016 Aug 23. PMID: 27687052.

14. Kunt AG, Kurtcephe M, Hidiroglu M, Cetin L, Kucuker A, Bakuy V, et al. Comparison of original EuroSCORE, EuroSCORE II and STS risk models in a Turkish cardiac surgical cohort. Interact Cardiovasc Thorac Surg. 2013 May;16(5):625-9. doi: 10.1093/ icvts/ivt022. Epub 2013 Feb 12. PMID: 23403767; PMCID: PMC3630432.

15. Atik FA, Cunha CR. Impact of type of procedure and surgeon on EuroSCORE operative risk validation. Rev Bras Cir Cardiovasc. 2014 Apr-Jun;29(2):131-9. doi: 10.5935/1678-9741.20140023. PMID: 25140461; PMCID: PMC4389461.

Received: 06.01.2021 